\title{
Implementasi Pembelajaran Daring (Program BDR) Selama Pandemi Covid-19 di Provinsi Jawa Barat
}

\author{
Rina Mutaqinah" ${ }^{\# 1}$, Taufik Hidayatullah ${ }^{\# 2}$ \\ Widyaiswara LPMP Jawa Barat, Jurusan Ilmu Komunikasi Universitas Pasundan \\ Kab.Bandung Barat, Kota Bandung \\ ${ }^{1}$ rina.mutaqinahekemdikbud.go.id \\ 2taufik.hidayatullah@unpas.ac.id
}

\begin{abstract}
Facing the Covid-19 pandemic, teachers, parents, school principals, must change the learning pattern from face-to-face learning to online learning, all parties must prepare all the tools to facilitate this online learning in a very urgent time, besides the curriculum targets that have not yet reached because the pandemic occurred in the middle of the semester. Likewise with the media that schools and parents must prepare in online learning, such as computers / laptops and internet-based cell phones. The Ministry of Education and Culture issued circular letter No.2 of 2020 regulating the technical implementation of distance learning or home learning $(B D R)$ in each region. This study aims to determine the implementation of distance learning at the SD, SMP, SMA and SMK levels in all districts / cities of West Java. Data were collected through surveys, data analysis using thematic analysis of qualitative data. The results of the analysis show: 1) Preparation and planning, carried out through a circular letter from the Minister of Education and Culture and Local Government are welcomed by schools and continued by socializing to school residents and parents through social media, teachers make BDR plans online with the application; 2). The process, media and learning resources are carried out online through social media, Facebook, WA, IG, Youtube and video; 3) Constraints, the obstacles faced by the teacher are in the form of limited quota / network, difficulty controlling students, while for parents access to the internet and limited gadget facilities as well as difficulties in managing the time and process of accompanying children to learn; and 4). The impact of BDR, curriculum targets are not optimally achieved, moral assessment is difficult to do. For parents, the impact of BDR feels that they have a better understanding of the learning difficulties experienced by children. In general, the success of online learning in West Java during the Covid-19 pandemic was determined by the readiness of infrastructure in the form of internet access and gadged facilities, support and collaboration from all stakeholders, including government, schools, teachers and parents as well as the readiness /skills of teachers in planning. and carry out the online learning process.
\end{abstract}

Keywords: learning, distance;pandemic,covid-19

Abstrak -Menghadapi pandemi Covid-19, guru, orang tua, kepala sekolah, harus mengubah pola pembelajaran dari pembelajaran tatap muka menjadi pembelajaran daring, semua pihak harus menyiapkan semua perangkat dalam memfasilitasi pembelajaran daring ini dalam waktu yang sangat mendesak, selain itu target kurikulum yang belum tercapai karena pandemic terjadi di tengahtengah semester. Begitupun dengan media yang harus disiapkan sekolah dan orang tua dalam pembelajaran daring ini, seperti komputer/laptop dan telepon seluler yang berbasis internet. Kemendikbud mengeluarkan surat edaran Nomor 2 Tahun 2020 mengatur pelaksanaan secara teknis pembelajaran jarak jauh atau belajar dari rumah (BDR) di setiap daerah. Penelitian ini bertujuan mengetahui imeplementasi pembelajaran jarak jauh di jenjang SD, SMP, SMA dan SMK di semua Kab./Kota Jawa Barat. Data dikumpulkan melalui survey, analisis data menggunakan analisis tematik data kualitatif. Hasil analisis menunjukkan: 1) Persiapan dan perencanaan, dilakukan melalui surat edaran Mendikbud dan Pemda disambut sekolah dan diteruskan dengan melakukan sosialisasi kepada warga sekolah dan orang tua melalui media sosial, guru membuat perencanaan BDR melalui daring dengan aplikasi; 2). Proses, media dan sumber pembelajaran, dilakukan secara daring melalui media sosial, Fb, WA, IG, Youtube dan video; 3) Kendala, kendala yang dihadapi guru berupa keterbatasan kuota/jaringan, kesulitan mengontrol siswa sedangkan bagi orang tua akses internet dan terbatasnya fasilitas gadget serta kesulitan mengatur waktu dan proses mendampingi anak belajar; dan 4). Dampak BDR, target kurikulum tidak secara optimal tercapai, penilaian akhlaq sulit dilakukan. Bagi orang tua dampak BDR merasa menjadi lebih paham kesulitan belajar yang dialami anak. Secara umum, keberhasilan pembelajaran online di Jawa Barat selama pandemi Covid-19 ditentukan oleh kesiapan infrastruktur berupa akses internet dan fasilitas gadged, dukungan dan kolaborasi dari semua pemangku kepentingan, termasuk pemerintah, sekolah, guru dan orang tua serta kesiapan/ keterampilan guru dalam membuat perencanaan dan melaksanakan proses pembelajaran daring

Kata Kunci: belajar; jarak; jauh; pandemic; covid-19 


\section{PENDAHULUAN}

Persebaran virus Corona yang massif di berbagai negara, memaksa kita untuk melihat kenyataan bahwa dunia sedang berubah. Kita bisa melihat bagaimana perubahan-perubahan di bidang teknologi, ekonomi, politik hingga pendidikan di tengah krisis akibat Covid-19. Perubahan itu mengharuskan kita untuk bersiap diri, merespon dengan sikap dan tindakan sekaligus selalu belajar hal-hal baru. Indonesia tidak sendiri dalam mencari solusi bagi siswa agar tetap belajar dan terpenuhi hak pendidikannya. Sampai 1 April 2020, UNESCO mencatat setidaknya 1,5 milyar anak usia sekolah yang terdamapk Covid 19 di 188 negara termasuk 60 jutaan diantaranya ada di negara kita [1]

Kejadian ini dialami tidak hanya di Indonesia tetapi di seluruh dunia, beberapa negara maju tidak terlalu membuat panik karena infrastruktur mereka sudah stabil dan lebih maju dibandingkan negara-negara berkembang seperti Indonesia. Berbagai inovasi bentuk daring pun mulai bermunculan, semua pihak mengembangkan berbagai bentuk-bentuk pembelajaran kreatif melalui daring. Begitu pun berbagai provider dan vendor internet, seakan berlomba menawarkan bentuk meeting secara daring seperti Zoom Meeting, Webex, Skype, Google Meet dan sebagainya.

Pengalaman dan keterbatasan skill dalam akses berbagai bentuk pembelajaran daring ini memaksa guru dan pihak sekolah untuk lebih aktif mempelajari dan mengembangkan pembelajaran mereka agar tujuan kurikulum tercapai walau dalam bentuk pembelajaran daring. Berbagai kendala tentunya banyak dihadapi, tetapi hal ini merupakan pembelajaran berharga bagi para guru dan sekolah untuk lebih kreatif dan inovatif membelajarkan siswanya.

Harian elektonik Bernas News [2], Jehamun menganalisis bahwa pembelajaran daring memang menjadi dilema bagi guru dan siswa. Di satu sisi, proses pembelajaran harus berjalan, di sisi lain berbagai problematika mengiringi proses pelaksanaannya mulai Pertama, masih banyak guru yang mempunyai keterbatasan dari sisi akses maupun pemanfaatan gawai yang dimiliki dan tidak semua guru punya kemampuan untuk mengoperasikan dan memanfaatkan gawai canggihnya. Kedua, kemandirian belajar siswa di rumah tidak dapat sepenuhnya dapat terlaksana dengan baik. Ketiga, tugas dan pekerjaan rumah yang diberikan guru membebani siswa. Keempat, tidak semua siswa mempunyai gawai (handphone). Kelima, pembelajaran daring terkendala dengan signal

Tidak hanya yang dialami guru dan pihak sekolah, di masa pandemi ini orang tua pun dituntut untuk belajar bagaimana mengajar, membimbing anak-anak mereka untuk bisa mengikuti pembelajaran secara daring yang diselenggarakan oleh gurunya, berbagai masalah, keluhan banyak diungkapkan di berbagai media sosial, bagaimana payahnya orang tua mendampingi putra putrinya untuk belajar di rumah, disamping tentunya mereka pun harus bekerja di rumah (WFH) bagi orang tua yang berkarir di luar rumah.

Bagi ibu bekerja bukan hanya mendampingi anak dan WHF mereka pun harus mengurus full time anggota keluarga di rumah, menyiapkan kebutuhan, memasak, mengurus rumah dan lain sebagainya [3].

Pada masa pandemi Covid-19 bentuk pembelajaran yang ditetapkan bagi siswa di Indonesia dalam bentuk pendidikan mandiri dan pembelajaran dengan e-learning serta kombinasi keduanya. Menurut surat edaran (SE) Mendikbud Nomor 2 Tahun 2020 tentang pencegahan corona virus disease (covid19) pada satuan Pendidikan, Mendikbud menginstruksikan pemerintah daerah mengeluarkan aturan pembelajaran di rumah untuk 3 kategori wilayah dan membuat pedoman pembelajaran daring. Petunjuk teknis pembelajarn di rumah yang dikeluarkan pemerintah daerah di Indonesia khususnya di Kab./ Kota di Jawa Barat semuanya berisi menghentikan pembelajaran luring (luar aringan) dan memberlakukan daring bagi semua satuan Pendidikan dengan memanfaatkan berbagai media daring yang disesuaikan dengan fasilitas yang dimiliki sekolah dan kemauan guru untuk menggunakannya.

Guna mengetahui implementasi dan kendala yang dihadapi Belajar dari Rumah (BDR) maka perlu dilakukan penelitian secara langsung melakukan survey terhadap penyelenggara pendidikan dan orang tua siswa. Tujuan penelitian ini untuk mengetahui: 1) implementasi BDR di Jawa Barat; 2) mengetahui kendala yang dihadapi selama BDR ini diimplementasikan.

\section{Tinjauan Pustaka}

\section{A. Konsep dan Karakteristik BDR}

BDR sebenarnya adalah Pendidikan Jarak Jauh (PJJ). Istilah BDR pertama kali dikenalkan pada saat munculnya pandemi covid19 di Indonesia, yakni sejak dikeluarkannya edaran Mendikbud Nomor 2 Tahun 2020 tentang Pencegahan dan Penanganan Covid-19 di lingkungan Kemdikbud [4], pembelajaran yang dilakukan di sekolah maupun di perguruan tinggi semuanya daring.

PJJ pertama kali dikenalkan oleh Wedemeyer di tahun 1965, saat itu Wedemeyer menyampaikan bahwa "...the extension student of the future will probably not 'attend' classes; rather, the opportunities and processes of learning will come to him. He will learn at home, at the office, on the job, in the factory, store, or salesroom, or on the farm." "...the teacher will reach students not only in his own state or region but nationally as well, since the media and methods employed by him in teaching will remove barriers of space and time in learning..." [5]. Wedemeyer memprediksi di masa depan siswa mungkin tidak akan menghadiri kelas; sebaliknya, kesempatan dan proses belajar akan datang padanya. Siswa akan belajar di rumah, kantor, tempat kerja, pabrik, toko, atau pasar, atau di pertanian. Guru akan menjangkau siswa tidak hanya di daerahnya, tetapi di negara 
bagian atau negara lainnya, karena media dan metode yang digunakan guru dalam mengajar akan menghilangkan hambatan ruang dan waktu dalam pembelajaran. Pada era digital ini apa yang diprediksi Wedemeyer semuanya terbukti, apalagi di era pandemic covid19 ini.

PJJ selama ini sudah diimplementasikan di Indonesia. PJJ atau distance learning di Indonesia selama ini banyak dilakukan oleh Universitas Terbuka (UT), sekolah terbuka seperti SMP Terbuka, SMA Terbuka. UT dan sekolah terbuka didirikan dengan tujuan mengatasi masalah keterbatasan jumlah guru dan guru. Dengan jumlah pulau yang lebih dari 13.000 an, jumlah penduduk lebih dari 220 juta orang serta keterbatasan infra struktur seperti alat transportasi, komunikasi dan sarana prasarana, maka solusi terbaik adanya sistem PJJ [6].

Mengutip Undang-Undang Sisdiknas tahun 2003 dalam Pasal 31 yang secara spesifik mengakomodasi PJJ, yaitu: a). Pendidikan jarak jauh dapat diselenggarakan pada semua jalur, jenjang, dan jenis Pendidikan; b). Pendidikan jarak jauh berfungsi memberikan layanan pendidikan kepada kelompok masyarakat yang tidak dapat mengikuti pendidikan secara tatap muka atau regular; c). Pendidikan jarak jauh diselenggarakan dalam berbagai bentuk, modus, dan cakupan yang didukung oleh sarana dan layanan serta sistem penilaian yang menjamin mutu lulusan sesuai dengan standar nasional Pendidikan; d). Ketentuan mengenai penyelenggaraan pendidikan jarak jauh sebagaimana dimaksud pada ayat (1), ayat (2), dan ayat (3) diatur lebih lanjut dengan Peraturan Pemerintah.

PJJ mengandung pengertian pemisahan pengajar dan pembelajar (walau tidak sepenuhnya). Kemandirian pembelajar diharapkan relatif lebih tinggi daripada kemandirian pembelajar pendidikan konvensional dan pemanfaatan media pembelajaran yang interaktif [7].

Stewart, Keegen dan Holmberg [6] membedakan tiga teori utama tentang pembelajaran jarak jauh yaitu otonomi dan belajar mandiri, industrialisasi pendidikan, dan komunikasi interaktif. Otonomi dan belajar mandiri yakni berupa kebebasan bagi siswa untuk belajar secara mandiri sesuai dengan kebutuhannya.

Program pendidikan mandiri adalah proses belajar yang dilakukan oleh siswa baik dalam lingkungan sekolah maupun diluar sekolah dengan cara membaca, menelaah serta memahami pengetahuan sesuai dengan materi pelajaran yang terkait.

Secara teknis siswa menentukan tujuan yang ingin dicapai, bahan/ sumber belajar yang ingin dipelajari, menentukan waktu belajar, dan menentukan cara mengevaluasi dan merefleksi diri dalam belajar.

Menurut Keegan [8] tingkat kemandirian siswa dalam belajar berbeda-beda, dan dibagi menjadi empat tingkat dalam program pembelajaran dapat dilihat dalam Tabel 1.
Tabel I

Tipe Program Pembelajaran Mandiri Dilihat dari Tingkat Kemandiriannya

\begin{tabular}{|c|c|c|c|c|c|}
\hline $\begin{array}{l}\text { Tingkat } \\
\text { Keman } \\
\text { dirian }\end{array}$ & No & $\begin{array}{c}\text { Tipe/Nama } \\
\text { Prog. } \\
\text { Pembela } \\
\text { jaran }\end{array}$ & $\begin{array}{c}\text { Dalam } \\
\text { merumus } \\
\text { kan tujuan }\end{array}$ & $\begin{array}{l}\text { Dalam } \\
\text { melaksa } \\
\text { nakan } \\
\text { pembela } \\
\text { jaran }\end{array}$ & $\begin{array}{c}\text { Dalam } \\
\text { menentu } \\
\text { kan } \\
\text { kriteria } \\
\text { evaluasi }\end{array}$ \\
\hline \multirow{3}{*}{$\begin{array}{l}\text { Siswa } \\
\text { mandiri } \\
\text { dalam } \\
\text { menent } \\
\text { ukan } \\
\text { tujuan, } \\
\text { cara } \\
\text { belajar } \\
\text { dan } \\
\text { evaluasi } \\
\text { (M) }\end{array}$} & 1. & $\begin{array}{l}\text { Program } \\
\text { Belajar } \\
\text { Sendiri } \\
\end{array}$ & M & M & M \\
\hline & 2. & $\begin{array}{l}\text { External } \\
\text { Degree } \\
\text { Prog di } \\
\text { Univ. } \\
\text { London }\end{array}$ & M & M & $\mathrm{T}$ \\
\hline & 3. & $\begin{array}{l}\text { Belajar } \\
\text { keterampil } \\
\text { an dalam } \\
\text { olahraga }\end{array}$ & M & $\mathrm{T}$ & M \\
\hline 个 & 4. & $\begin{array}{l}\text { Prog. } \\
\text { Pembel.yg } \\
\text { pelajaran } \\
\text { dan } \\
\text { evaluasi } \\
\text { nya } \\
\text { dikontrol } \\
\text { siswa } \\
\end{array}$ & $\mathrm{T}$ & M & M \\
\hline & 5. & $\begin{array}{l}\text { Belajar } \\
\text { mengenda } \\
\text { rai mobil }\end{array}$ & M & $\mathrm{T}$ & $\mathrm{T}$ \\
\hline & 6. & $\begin{array}{l}\text { Prog. } \\
\text { Pembel.yg } \\
\text { evaluasi } \\
\text { nya } \\
\text { dikontrol } \\
\text { siswa }\end{array}$ & $\mathrm{T}$ & $\mathrm{T}$ & M \\
\hline Guru & 7. & $\begin{array}{l}\text { Kuliah } \\
\text { mandiri } \\
\text { indepen } \\
\text { den }\end{array}$ & $\mathrm{T}$ & $\mathrm{M}$ & $\mathrm{T}$ \\
\hline $\begin{array}{l}\text { menent } \\
\text { ukan } \\
\text { tujuan } \\
\text { cara } \\
\text { belajar } \\
\text { dan } \\
\text { evaluasi } \\
\text {, siswa } \\
\text { tidak } \\
\text { mandiri }\end{array}$ & 8. & $\begin{array}{l}\text { Belajar } \\
\text { bebas } \\
\text { untuk } \\
\text { mendapat } \\
\text { kan kredit }\end{array}$ & $\mathrm{T}$ & $\mathrm{T}$ & $\mathrm{T}$ \\
\hline
\end{tabular}

Diadaptasi dari Types of Independent Study Programmes by Variable Learner Autonomy tulisan Moore, dalam Desmond Keegan 1983, 1991)

Berdasarkan tipe program pembelajaran mandiri dilihat dari tingkat kemandiriannya pada tabel 1 maka BDR pada saat ini termasuk tipe ketujuh yakni program kuliah mandiri independent atau pembelajaran mandiri independen, sebab dalam BDR tujuan pembelajaran dan kriteria evaluasi 
ditentukan oleh guru, siswa hanya melaksanakan pembelajaran secara mandiri.

Sedangkan industrialisasi pendidikan menurut Keegan pada awalnya merupakan pemikiran mengenai sistem PJJ yang didominasi oleh pengertian sebagai suatu bentuk pendidikan yang didasarkan pada penggunaan bahan ajar standar yang diproduksi secara masal untuk mencapai keuntungan ekonomis (economies of scale). Pemikiran ini mencerminkan paradigma yang menekankan pada isu aksesibilitas sebagai fokus penyelenggaraan pendidikan.

PJJ merupakan produk masyarakat era industri dan sebagai suatu sistem, PJJ mempunyai banyak persamaan dengan suatu proses produksi industri (pabrik). Keduanya mempunyai kesamaan karakteristik dalam hal adanya pembagian tugas yang jelas antara pekerja (division of labour), mekanisasi, produksi massa, standardisasi output, dan sentralisasi sistem. Kesesuaian sistem PJJ dengan situasi masyarakat industri inilah maka sistem PJJ ini dapat diterima oleh masyarakat dan berhasil digunakan untuk meningkatkan jumlah sumber daya manusia terdidik. Oleh karena itu, menurut Peters, seiring dengan perubahan tatanan masyarakat dari era industrialisasi ke era pasca industrialisasi (post-industrial society), maka sistem PJJ pun harus mengalami perubahan [8]. Pada era industri, proses PJJ dilakukan dengan memproduksi bahan ajar cetak yang bersifat masal serta dilakukan melalui surat menyurat (correspondence study).

\section{B. Interaksi Pembelajaran Jarak Jauh}

Interaksi pada pembelajaran jarak jauh tentunya berbeda dengan interaksi yang dilakukan secara tatap muka, dalam interaksi jarak jauh. Sholosser dan Anderson (1994) dengan mengacu kepada teori Desmon Keegan, menerangkan dalam sistem pembelajaran jarak jauh harus mampu menciptakan interaksi belajar mengajar yang sesungguhnya tidak ada (abstrak) tetapi mewujudkannya seperti seolah-olah siswa dan guru berada di suatu ruangan yang sama. Pendidikan jarak jauh memerlukan interaksi yang tinggi antara guru dan siswa, sekalipun di wilayah terpencil. Manfaat interaksi ini adalah; pembelajaran jarak jauh memperbolehkan siswa untuk mendengar dan mungkin melihat gurunya, sebagaimana keharusan guru untuk menjawab pertanyaan atau komentar dari siswanya.

Pada saat ini Interaksi sosial dalam kehidupan sehari-hari dipengaruhi oleh pemakaian smartphone. Smartphone yang dapat masuk di semua kalangan dan pemakainnya tidak terbatas ruang dan waktu tentunya memberikan peran penting dalam suatu interaksi sosial. Pemakaian smartphone di semua kalangan tersebut tentunya juga memasuki ranah hubungan antara guru dengan siswa, siswa dengan siswa, maupun siswa dengan orang luar. Hubungan komunikasi antar siswa dengan lingkungannya.

Wilbur Schramm mengemukakan model komunikasi interaksional yang menekankan proses komunikasi dua arah di antara para komunikator, elemen yang paling penting pada model ini adalah umpan balik (feed back) atau tanggapan terhadap suatu pesan. [9] Tanggapan pada pembelajaran merupakan factor terpenting untuk mencapai tujuan pembelajaran yang diharapkan dan proses interaksi gurusiswa, siswa-siswa, siswa-lingkungan sehingga tercipta proses yang menyenangkan membangun suasana belajar yang kondusif dan efektif.

Pembelajaran pada dasarnya merupakan suatu proses terjadinya interaksi antara guru dengan siswa melalui kegiatan terpadu dari dua bentuk kegiatan, yakni kegiatan belajar siswa dengan kegiatan mengajar guru. Belajar pada hakikatnya adalah proses perubahan tingkah laku yang disadari. Mengajar pada hakikatnya adalah usaha yang direncanakan melalui pengaturan dan penyediaan kondisi yang memungkinkan siswa melakukan berbagai kegiatan belajar sebaik mungkin. Tentunya pengaturan dan penyediaan berbagai kegiatan yang efektif dan menyenangkan sangat tergantung pada kemampuan guru mengelola pembelajaran mulai kegiatan awal, inti dan penutup, yang memungkinkan suasana pembelajaran yang dibangun menjadi menyenangkan dan efektif.

Pada pembelajaran daring komunikasi guru dan siswa telah menemukan jalur baru yang mengedepankan aspek efektifitas, efisiensi, dan keterbukaan. Melalui daring komunikasi dengan guru lebih mudah. Umumnya komunikasi ini dilakukan untuk urusan jadwal, diskusidiskusi materi yang disampaikan di grup WA, dan untuk membaca atau mendownload materi yang disajikan guru melalui e-learning. Selain itu diskusi di grup WA atau $e$ learning lebih membuat siswa tidak grogi atau tidak malu karena tidak langsung bertemu dengan guru [10].

Selain itu interaksi pembelajaran secara daring dapat dilakukan dengan berbagai cara guru dapat menggunakan variasi metode yang melibatkan siswa baik secara emosi maupun kognisi. Berbagai game dapat dibuat oleh guru untuk menciptakan interaksi pembelajaran yang efektif dan menyenangkan. Berbagai platform menyediakan berbagai metode atau game tersebut baik yang berbayar maupun yang free. Beberapa platform penyedia games, kuis interaktif adalah Mentimeter, Slido, Padlet, Kahoot, Quiziz, Quizlet, Quipper, Seesaw dan sebagainya. Semuanya menawarkan kuis interaktif, curah pendapat, permainan edukatif. Akses dan penggunaannya sangat mudah, guru tinggal berselancar dan mengikuti petunjuk pada menu-menu yang telah disediakan.

\section{Metode Penelitian}

Penelitian ini menggunakan metoda survey, menurut Scheuren kata survei paling sering digunakan untuk menjelaskan metode pengumpulan informasi dari sampel individu. Selain sampel dan pengumpulan informasi, istilah berulang lainnya dalam definisi dan deskripsi sistematis atau 
terorganisir dan kuantitatif. Jadi, survei bisa dilihat sebagai strategi penelitian di mana informasi kuantitatif dikumpulkan secara sistematis dari sampel yang relatif besar yang diambil dari suatu populasi [11]. Rancangan survey adalah prosedur penelitian yang mana peneliti melaksanakan survei atau memberikan angket dengan skala tertentu pada satu sampel untuk menggambarkan sikap, opini, perilaku, atau karakteritik responden. Dari hasil survei ini, peneliti membuat pandangan tentang kecenderungan yang ada dalam populasi.

Jadi metode survey adalah metode penelitian yang mengkaji populasi dengan menggunakan metode sampel yang memiliki tujuan untuk mengetahui perilaku, karakteristik, dan membuat deskripsi serta generalisasi yang ada dalam populasi tersebut, dengan teknik kuesioner terbuka yang diberikan berbagai alternatif jawaban atas setiap pertanyaan dalam kuesioner. Kuesioner dikembangkan dua paket: 1) Paket A bagi Pelaksana Pendidikan yakni bagi unsur Disdik Kab./Kota, Guru, Kepala sekolah dan Pengawas; dan 2) paket $B$, bagi orang tua siswa semua jenjang mulai SD, SMP, SMA dan SMK di Jawa Barat.

Instrumen terbagi dua dengan maksud untuk mengetahui persepsi kedua pihak yakni pihak penyelenggara BDR dan pihak pengguna. Pihak penyelenggara terdiri dari berbagai unsur yakni unsur pejabat Disdik dan pihak sekolah, sedangkan pihak pengguna orang tua dari berbagai jenjang Pendidikan.

Jumlah responden sebanyak 32.378 responden terdiri dari 11.585 responden pelaksana pendidikan dan 20.793 responden orang tua siswa. Responden berasal dari seluruh kabupaten dan kota ( 27 Kab./ Kota) di Jawa Barat.

Butir pertanyaan pada survey sebanyak 48 butir dari 10 indikator dan 5 aspek, yakni aspek 1) Persiapan dan perencanaan; 2). Proses, media dan sumber pembelajaran; 3) Kendala; dan 4). Dampak BDR. Sedangkan indikator: 1). Cara Pemda melakukan sosialisasi BDR; 2). Cara sekolah melakukan sosialisasi kebijakan BDR; 3) Cara sekolah/ guru membuat perencanaan BDR; 4). Persiapan infrastruktur selama BDR ; 5). Penggunaan berbagai media pembelajaran oleh guru; 6) penggunaan sumber belajar selama BDR; 7). Hambatan yang dihadapi dalam penyelenggaraan BDR; 8) Pencapaian target kurikulum selama BDR; 9) pemantauan yang dilakukan pihak Disdik selama BDR; 10) Cara guru melakukan penilaian dan evaluasi selama BDR.

Pengumpulan instrumen dilakukan melalui google form selama bulan April 2020. Data yang digunakan adalah data primer hasil survey. Pengolahan dan analisis data yang digunakan dalam penelitian ini meliputi kegiatan reduksi data, penyajian data dan penarikan kesimpulan. Reduksi data dan sajian data disusun pada waktu peneliti mendapatkan data yang diperlukan dalam penelitian. Setelah pengumpulan data berakhir, peneliti berusaha menarik kesimpulan berdasarkan verifikasi data lapangan tersebut.

\section{HASIL DAN PEMBAHASAN}

Responden penyelenggara Pendidikan sebanyak 11.585 orang dengan jumlah responden berdasarkan jabatan, pada grafik berikut ini:

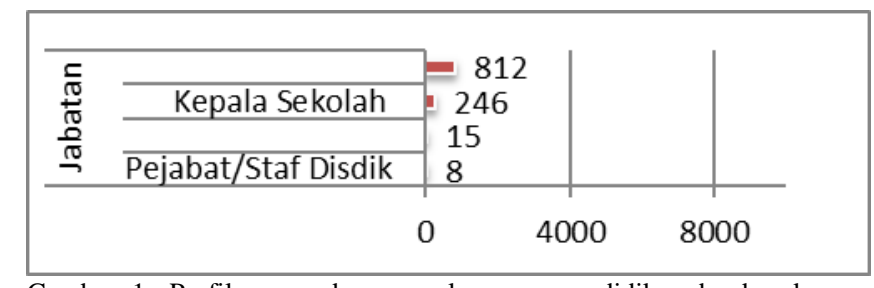
jabatan

Hasil penelitian yang dilakukan bagi penyelenggara pendidikan yang meliputi tiga aspek: 1) Persiapan dan perencanaan; 2) Proses, media dan sumber belajar; dan 3) Kendala yang dihadapi, setiap indikator ditunjukkan pada tabel sebagai berikut:

Tabel II

Rekapitulasi Hasil Survey Bagi Penyelenggara Pendidikan (Disdik, Kepala Sekolah Dan Guru)

\begin{tabular}{|c|c|c|}
\hline Aspek & Jawaban Responden & $\%$ \\
\hline \multirow[t]{3}{*}{$\begin{array}{l}\text { 1). Persiapan } \\
\text { dan perencana } \\
\text { an }\end{array}$} & $\begin{array}{l}\text { Memberikan surat edaran yang } \\
\text { mengintruksikan dilakukannya } \\
\text { BDR yakni sebesar }\end{array}$ & 87.8 \\
\hline & $\begin{array}{l}\text { Meneruskan surat edaran dari } \\
\text { Pemda/Disdik tentang } \\
\text { kebijakan BDR selama covid- } \\
19\end{array}$ & 92,5 \\
\hline & $\begin{array}{l}\text { Guru membuat perencanaan } \\
\text { pembelajaran BDR secara } \\
\text { sistematis (terjadwal dan } \\
\text { terstruktur) }\end{array}$ & 70,2 \\
\hline \multirow[t]{6}{*}{$\begin{array}{l}\text { 2). Proses, } \\
\text { media dan } \\
\text { sumber belajar }\end{array}$} & $\begin{array}{l}\text { Sekolah memfasilitasi guru } \\
\text { untuk memberikan } \\
\text { pembelajaran online }\end{array}$ & 78,3 \\
\hline & Media social (Fb,IG,WA) & 90,1 \\
\hline & $\begin{array}{l}\text { Media elektronik: TVRI, } \\
\text { Radio,Video }\end{array}$ & 90,0 \\
\hline & $\begin{array}{l}\text { Guru lebih focus pada BDR } \\
\text { yang tidak membebankan siswa } \\
\text { dalam jam belajar }\end{array}$ & 50,1 \\
\hline & $\begin{array}{l}\text { Terdapat pemantauan yang } \\
\text { dilakukan oleh } \\
\text { Pemda/Disdik/pengawas } \\
\text { sekolah }\end{array}$ & 75,9 \\
\hline & $\begin{array}{l}\text { Guru memberikan pertanyaan } \\
\text { sebagai bentuk post tes kepada } \\
\text { siswa setelah materi pelajaran } \\
\text { selesai }\end{array}$ & 59,9 \\
\hline $\begin{array}{l}\text { 3). Kendala } \\
\text { yang dihadapi } \\
\text { dalam } \\
\text { penyelenggaraa } \\
\text { n BDR }\end{array}$ & $\begin{array}{l}\text { Keterbatasan siswa/ orang tua } \\
\text { dalam menggunakan media } \\
\text { online }\end{array}$ & 78,8 \\
\hline
\end{tabular}


Kuesioner yang diberikan kepada 20.793 responden orang tua diperoleh prosentase responden terdapat pada grafik berikut ini:

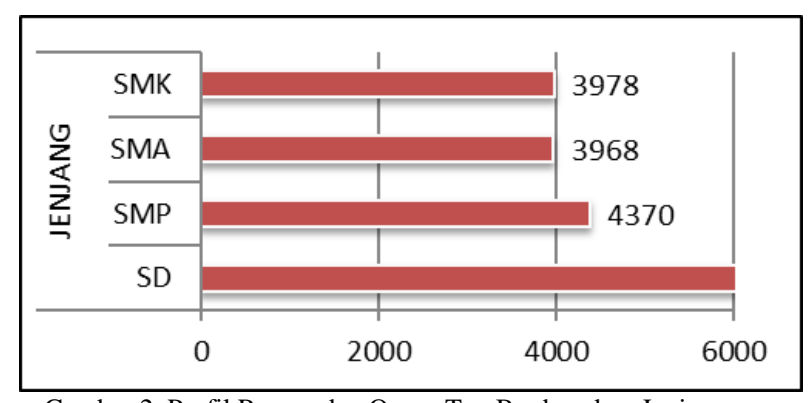

Pendidikan

Gambar 2. Profil Responden Orang Tua Berdasarkan Jenjang

Hasil survey kepada responden orang tua pada semua jenjang, dengan indikator: 1) Keterlibatan Orang tua selama BDR; 2). Hambatan orang tua dalam mendampingi anak selama BDR; 3). Pemantauan oleh orang tua di rumah selama BDR; 4) Penilaian dan evaluasi oleh guru selama BDR; 5). Dampak BDR terhadap siswa; dan 6). Dampak BDR terhadap orang tua siswa, sebagai berikut:

Tabel III

Rekapitulasi Hasil Survey dengan Prosentase Tertinggi untuk Responden Orang Tua Siswa (Jenjang SD, SMP, SMA, SMK)

\begin{tabular}{|c|c|c|}
\hline Aspek & Jawaban Responden & $\%$ \\
\hline \multirow[t]{4}{*}{$\begin{array}{l}\text { 1) Proses } \\
\text { pembelajaran }\end{array}$} & $\begin{array}{l}\text { Tidak semua orang tua dapat } \\
\text { mendampingi anaknya selama BDR }\end{array}$ & 43,1 \\
\hline & $\begin{array}{l}\text { Orang tua kesulitan memantau anak } \\
\text { untuk memastikan BDR sesuai } \\
\text { target/tugas dari sekolah }\end{array}$ & 58,1 \\
\hline & $\begin{array}{l}\text { Guru setiap hari meminta siswa/ } \\
\text { orang tua untuk mengisi lembar } \\
\text { pemantauan belajar/ sikap melalui } \\
\text { format tertentu }\end{array}$ & 43,5 \\
\hline & $\begin{array}{l}\text { Guru memberikan pertanyaan sebagai } \\
\text { bentuk post tes kepada siswa setelah } \\
\text { materi pelajaran selesai }\end{array}$ & 39,9 \\
\hline $\begin{array}{lr}2) . & \text { Kendala } \\
\text { orang } & \text { tua } \\
\text { dalam } & \\
\text { mendampingi } \\
\text { anak } & \text { selama } \\
\text { BDR } & \end{array}$ & $\begin{array}{l}\text { Orang tua kesulitan dalam hal } \\
\text { mengatur waktu bekerja di rumah dan } \\
\text { mendampingi anaknya BDR }\end{array}$ & 44,6 \\
\hline \multirow[t]{7}{*}{ 3). Dampak } & $\begin{array}{l}\text { Guru memberikan ulangan/ tes setiap } \\
\text { akhir materi tematik/ per KD atau per } \\
\text { akhir pekan }\end{array}$ & 24,8 \\
\hline & BDR membuat siswa 'enjoy' & 29,2 \\
\hline & $\begin{array}{l}\text { BDR membuat siswa terburu-buru } \\
\text { belajar }\end{array}$ & 25,5 \\
\hline & BDR membuat siswa disiplin & 24,2 \\
\hline & BDR membuat siswa stress & 27,2 \\
\hline & $\begin{array}{l}\text { BDR membuat orang tua memahami } \\
\text { kondisi/ kesulitan anak }\end{array}$ & 59,3 \\
\hline & $\begin{array}{l}\text { BDR membuat orang tua memiliki } \\
\text { kesempatan dekat dengan anak }\end{array}$ & 41,7 \\
\hline
\end{tabular}

Terdapat indikator butir yang berbeda antara kuesioner bagi penyelenggara pendidikan dan orang tua, secara deskriptif disampaikan untuk memberikan gambaran yang luas dalam memotret implementasi BDR di Jawa Barat dari dua persepsi yakni persepsi penyelenggara dan pengguna.

Berdasarkan hasil survey penyelenggara pendidikan pada tabel 2 aspek persiapan dan perencanaan menunjukkan bahwa sosialisasi BDR hampir semua sekolah mendapatkan sosialisasi BDR melalui surat edaran dari Disdik Kab./ Kota dan Provinsi dan sekolah meneruskannya kepada warga sekolah dan orang tua siswa. Hal ini menunjukkan bahwa Disdik Kab./ Kota dan Provinsi cepat dalam menanggapi kondisi darurat pandemi civid-19, bahkan ada sebagian Disdik sudah membuat petunjuk teknis pembelajaran selama pandemi covid-19, yakni terdapat 8 Kab./ Kota di Jawa Barat dan Disdik Provinsi Jawa Barat yang menyiapkan petunjuk teknis pembelajaran dari rumah bagi sekolah di wilayahnya di masa pandemi Covid-19.

Pada aspek perencanaan guru menghadapi pandemi covid-19, hampir semua sekolah dan Pemerintah Daerah membuat persiapan berupa infrastruktur yang mendukung terhadap pembelajaran jarak jauh, responden $78,3 \%$ Begitupun dengan perencanaan pembelajaran yang dilakukan guru di masa pandemi ini, guru menunjukkan siap menjalankan BDR terbukti dengan prosentase sebesar 70,2 \% responden dari unsur penyelenggara Pendidikan menyatakan guru telah membuat perencanaan pembelajaran BDR. Media pembelajaran yang digunakan guru hampir semuany yakni 90,1 \% menyatakan menggunakan media sosial seperti facebook, IG, dan WA, sedangkan sumber belajar yang sering digunakan BDR yakni TVRI, radio sebesar $90 \%$.

Pada aspek perencanaan ini baik Disdik, sekolah tidak memperhitungkankan dan mengantisipasi perencanaan yang berkaitan dengan fasilitasi siswa dalam sarana prasarana, ketersediaan alat dan teknologi, sehingga hal ini menjadi masalah terbesar yang dihadapi dihampir semua jenjang Pendidikan dan kab./ kota di Jawa Barat, bahkan mungkin tidak hanya di Jawa Barat terlebih lagi di provinsi lainnya yang secara infrastruktur belum memadai.

Persiapan atau perencanaan yang mengantisipasi ketersediaan alat dan teknologi ini sangat berpengaruh pada partisipasi siswa dalam mengikuti pembelajaran secara daring termasuk partisipasi dalam mengumpulkan tugastugas sekolah. Dari hasil jawaban terbuka guru menyampaikankan bahwa siswa sulit memahami materi yang disampaikan guru melalui daring seperti video conference dengan platform Zoom Meeting sehingga guru harus berulanulang menyampaikan penjelasan.

Pada perencanaan yang dibuat sekolah atau pun guru idealnya sekolah/ guru membuat perencanaan alternatif terkait dengan ketersediaan sarana prasarana yang dimiliki siswa dan atau keterbatasan kemampuan siswa memahami pembelajaran secara tidak langsung, beberapa siswa dengan gaya belajar tertentu lebih sulit memahami materi jika tidak 
bertatap muka secara langsung. Alternatif perencanaan yang dimaksud seperti bahan-bahan belajar yang dirancang secara offline atau dapat diakses dengan media sosial yang familiar bagi siswa dan orang tua.

Aspek proses dan sumber pembelajaran, sekolah memfasilitasi guru untuk memberikan pembelajaran online sebesar $70,2 \%$ dan media yang digunakan guru dalam melaksanakan pembelajaran daring adalah media sosial seperti $\mathrm{Fb}$, IG,WA sebesar 90,1\% dan media elektronik seperti TVRI, radio dan video $90 \%$. Dalam pelaksanaannya walaupun tidak secara eksplisit sekolah menentukan alteratifalternatif pembelajaran daring, guru sudah berinisiatif memanfaatkan media sosial dan elektrinik untuk memperkuat pembelajaran yang diberikan.

Hal ini sejalan dengan pendapat Watie bahwa muncul dan berkembangnya internet membawa cara komunikasi baru di masyarakat. Media sosial hadir dan merubah paradigma berkomunikasi di masyarakat saat ini (Watie, 2011) [12]. Saat ini media sosial merupakan media nomor satu dalam perkembangan komunikasi digital di dunia, semua pengguna telepon seluler mereka menggunakan media social seperti WhatsApp, Instagram, Facebook dan Youtube sebagai alat komunikasi mereka. Pengguna telepon seluler khususnya remaja dan anak-anak usia sekolah banyak menghabiskan waktunya hanya untuk bermedia sosial, seperti pendapat yang dikemukakan oleh Hoechsmann dan Poyntz (Michael Hoechsmann \& Poyntz, 2012).

Hasil survey pada aspek kendala yang dihadapi penyelenggara BDR yakni Disdik, Pengawas, Kepala Sekolah dan Guru menunjukkan bahwa kendala yang dihadapi yakni Sebagian besar orang tua $(78,8 \%)$ kesulitan dalam hal mengatur waktu bekerja di rumah dan mendampingi anaknya BDR.

Hasil survey dengan pertanyaan terbuka menunjukkan, jawaban guru antara lain: 1) guru melaksanakan pembelajaran dengan jadwal yang fleksibel; 2) secara durasi waktu pembelajaran formalnya lebih pendek namun berkelanjutan secara informal bahkan 24 jam guru harus melayani siswa berkonsultasi materi pembelajaran; 3) belum menguasai teknik pembelajaran daring; 4) belum menguasai cara mengakses internet; 5) sinyal dan jaringan internet buruk; 6) keterbatasan dalam menyajikan materi yang memerlukan percobaan, pengalaman langsung dengan obyek, bahan-bahan kimia, dan benda nyata lainnya; 7) target kurikulum yang tidak bisa maksimal tercapai; 8) terbatasnya kemampuan guru mengembangkan media pembelajaran daring dan metode pembelajaran interaktif secara daring.

Kendala lainnya dari pihak Disdik dan Pengawas berdasarkan jawaban atas pertanyaan terbuka antara lain, diambil lima jawaban terbanyak: 1) keluhan-keluhan sekolah yang berada di daerah pegunungan dan lembah yang kesulitan untuk akses internet, dimana pihak Disdik sulit menyediakan sarana lain sebagai alternatif; 2) banyak program-program peningkatan mutu di daerah semuanya terhenti dan alokasi dana dialihkan pada subsidi berupa alatalat kesehatan dan keselamatan; 3) sekolah mengeluh tidak ada fasilitas bagi guru untuk mendapatkan akses media dalam melaksanakan pembelajaran daring; 4) orang tua mengeluh banyak mengeluh terbatasnya gadget dan pulsa bagi anakanak mereka; 5) target pencapaian kurikulum tidak terpenuhi.

Hasil survey kepada orang tua siswa terdiri dari tiga aspek yakni: 1) proses pembelajaran; 2) kendala orang tua dalam mendampingin anak selama BDR; dan 3) Dampak BDR. Berdasarkan hasil penelitian yang ditunjukkan pada tabel 3 menunjukkan aspek proses pembelajaran BDR: 1) Keterlibatan Orang tua selama BDR, jawaban responden tertinggi yakni "tidak semua orang tua dapat mendampingi anaknya selama BDR", artinya selama masa pandemi Covid$19 \%$ walaupun orang tua ada di rumah dan bekerja di rumah atau Work from Home (WFH) ternyata $43,1 \%$ orang tua tidak dapat mendampingi anaknya belajar. Respon lainnya Orang tua kesulitan dalam hal mengatur waktu bekerja di rumah dan mendampingi anaknya BDR sebesar 44,6\%. Respon lainnya "Orang tua kesulitan memantau anak untuk memastikan BDR sesuai target/tugas dari sekolah" sebesar $58,1 \%$.

Dari ketiga respon tersebut banyak faktor yang menjadi penyebabnya, salah satunya menurut Sulvi Sofiana [13], anak terus mendapat tugas secara online yang dikumpulkan harian, serta mengerjakan tugas di lembar kerja siswa, tetapi anak minim mendapatkan penjelasan akan materi yang ditugaskan sehingga hal ini menyulitkan orang tua untuk membantunya belajar, di sisi lain banyak pekerjaan rumah atau kantor yang harus dikerjakan orang tua secara bersamaan.

Penilaian oleh guru selama BDR, menunjukkan guru setiap hari meminta siswa/ orang tua untuk mengisi lembar pemantauan belajar/ sikap melalui format tertentu sebesar 43,5\% dan 39,9\% menjawab "Guru memberikan pertanyaan sebagai bentuk post tes kepada siswa setelah materi pelajaran selesai". Hal ini menunjukkan Sebagian guru sudah melakukan pemantauan ketercapaian tujuan pembelajaran dengan memberikan siswa tes. Sebagian guru lainnya tidak memberikan penilaian atas ketercapaian tujuan pembelajaran Penilaian sebagai tolok ukur dan bertujuan mengukur tercapainya tujuan pembelajaran (Stiggins, 1994) [14]. Jika penilaian tidak dilakukan oleh guru dari mana guru dapat mengetahui keberhasilan pembelajaran yang dilakukannya. Masa pandemi Covid-19 secara tiba-tiba telah membuat guru tidak memiliki persiapan yang cukup dalam menyelenggarakan pembelajaran jarak jauh (daring).

Dalam Permendiknas No. 16 Tahun 2007 menyatakan bahwa guru harus memiliki kompetensi pedagogi yakni guru harus dapat memanfaatkan teknologi dan informasi untuk kepentingan pembelajaran [15]. Jadi sebenarnya tidak ada alasan bagi guru terutama guru-guru yang sudah tersertifikasi profesi guru (guru profesional), sehingga ketika memasuki era pembelajaran daring sudah tidak perlu lagi bingung dan panik karena tidak menguasai TIK. 
Aspek dampak BDR bagi siswa dan orang tua, jawaban responden menunjukkan guru memberikan ulangan/ tes setiap akhir materi tematik/ per KD atau per akhir pekan $24,8 \%$; BDR membuat siswa 'enjoy' $29,2 \%$; BDR membuat siswa terburu-buru belajar 25,5\%; BDR membuat siswa disiplin 24,2\%; BDR membuat siswa stress $27,2 \%$; BDR membuat orang tua memahami kondisi/ kesulitan anak 59,3\%; BDR membuat orang tua memiliki kesempatan dekat dengan anak $41,7 \%$. Prosentase responden dalam menjawab rata-rata sebesar $33 \%$. Prosentase tertinggi dalam indikator dampak BDR bagi orang tua yakni orang tua memahami kondisi/kesulitan anak dalam belajar sebesar 59,3\% responden.

Berbagai kondisi letak geografis tempat tinggal siswa yang beragam menjadi masalah terutama ketersediaan dan stabilitas sinyal internet. Tempat tinggal siswa ada yang di daerah dataran rendah, seperti dataran di lembah dan tepi laut, ada juga siswa yang tinggal di dataran tinggi, seperti di pegunungan, perbukitan atau lereng gunung. Ada yang tinggal di kota, ada pula siswa yang tinggal di desa. Stabilitas sinyal internet diperlukan agar dalam proses pembelajaran tidak terganggu sehingga siswa dapat mengikuti pembelajaran dengan baik, tetapi tidak hanya sinyal, pulsa (kuota data) internet harus tersedia. Padahal pembelian pulsa (kuota) data memerlukan biaya yang tidak murah.

Indikator lainnya pada aspek dampak menunjukkan prosentase yang hampir merata dialami oleh kurang lebih $25 \%$ orang tua menyatakan dampak yang negatif bahkan $27,2 \%$ orang tua menyatakan putra-putri mereka stress dengan pembelajaran BDR, tetapi $29,2 \%$ menyatakan anakanak mereka enjoy, artinya untuk Sebagian siswa dan orang tua BDR membuat mereka lebih menikmati belajar, kebersamaan dengan keluarga (orang tua dan anak). Anak dan orang tua dekat, waktu yang lebih leluasa dan kondisi rumah yang memadai ditambah tentunya perangkat dan jaringan internet memadai.

Hasil survey berupa jawaban atas pertanyaan terbuka mengenai dampak BDR bagi orang tua dan siswa, responden menyatakan, diambil lima jawaban terbanyak dengan adanya BDR: 1) kesempatan dekat dengan anak; 2) dapat mendampingi anak belajar dan memahami kesulitan anak; 3) anak menjadi keranjingan menggunakan gadget dan bermain 'games'; 4) menjadi lebih memahami kesulitan yang dihadapi guru-guru di sekolah; 5) kebutuhan gadget, pulsa dan listrik jadi meningkat.

Dari hasil survey proses pembelajaran, kendala dan dampak BDR bagi orang tua dan siswa ini, menunjukkan bahwa siswa dan orang tua sebagian besar belum siap untuk melaksanakan pembelajaran daring, walaupun saat ini pembelajaran daring adalah satu-satunya alternatif adalam menyelamatkan dan mengamankan warga negara menghadapi pandemi covid-19.

Dampak secara umum pandemi Covid-19 mengubah cara guru dan siswa belajar, menjadi gaya belajar yang menuntut literasi digital. Belajar bermula dibatasi ruang dan waktu menjadi belajar yang tidak terbatas ruang dan waktu dengan akses sumber belajar digital tanpa batas. Hal ini memerlukan keterampilan dan kearifan dalam mengakses, mengolah dan menggunakan informasi, seperti yang disampaikan Nasrullah bahwa strategi pengembangan literasi digital keluarga dimulai dari orang tua, karena orang tua harus menjadi teladan literasi dalam menggunakan media digital. Orang tua harus menciptakan lingkungan sosial yang komunikatif dalam keluarga, khususnya dengan anak. Membangun interaksi antara orang tua dan anak dalam pemanfaatan media digital dapat berupa diskusi, saling menceritakan pemanfaatan media digital yang positif [16].

Sedangkan hal lainnya mengenai kesempatan untuk komunikasi dalam pembelajaran daring menurut Stafford komunikasi sangat terbatas dalam persepsi individu masingmasing yang menjalani hubungan jarak jauh. Sulitnya komunikasi yang dilakukan karena keterbatasan alat serta tempat yang tidak strategis untuk berkomunikasi dengan lancar. [17]

Menurut Rogers dan Lawrence komunikasi adalah suatu proses di mana dua orang atau lebih membentuk atau melakukan pertukaran informasi dengan satu sama lainnya, yang pada akhirnya sampai pada saling pengertian yang mendalam [18]. Sedangkan menurut Harold D. Lasswell mendefinisikan komunikasi adalah "siapa yang menyampaikan, apa yang disampaikan, melalui saluran apa, kepada siapa, dan apa pengaruhnya". Lasswell juga menjelaskan fungsi pendidik sebagai pihak yang membantu menghubungkan/mengkorelasikan atau mengumpulkan respons orang-orang terhadap informasi baru serta anggota keluarga dan pendidik di sekolah dalam mengalihkan warisan sosial. Dalam modelnya, Lasswell menekankan khusus untuk pendidik, unsur "in which channel" perlu menjadi catatan khusus karena menekankan pada keberadaan saluran atau media yang membantu sampainya pesan dari komunikator kepada komunikan. Media disini disamping mempermudah sampainya pesan juga berfungsi untuk meningkatkan kualitas pembelajaran (learning quality) [19].

Sedangkan pengertian hubungan jarak jauh atau sering disebut dengan long distance relationship adalah dimana pasangan dipisahkan oleh jarak fisik yang tidak memungkinkan adanya kedekatan fisik untuk periode waktu tertentu.

Terdapat perbedaan dari kedua persepsi dari pihak penyelenggara BDR (Disdik, Pengawas, Kepala Sekolah dan Guru) dan pengguna (orang tua) dalam menyampaikan kendala yang dihadapi. Pihak penyelenggara menyatakan kendala yang dihadapi adalah keterbatasan siswa/ orang tua dalam menggunakan media online dengan perolehan peryataan sebanyak $78 \%$, prosentase ini cukup besar dimana kendala ini dirasakan sebagian besar guru, Kepala Sekolah dan Pengawas. 
Sedangkan dari pihak pengguna (orang tua) menyatakan bahwa kendala yang dihadapi dalam pembelajaran dari rumah adalah orang tua kesulitan dalam hal mengatur waktu bekerja di rumah dan mendampingi anaknya BDR. Pernyataan ini dinyatakan oleh $44,6 \%$ orang tua, yang lainnya sebanyak $40,7 \%$ menyatakan orang tua kesulitan dalam hal penguasaan materi pelajaran selama mendampingi anaknya, dan $32,3 \%$ menyatakan orang tua kesulitan dalam menyiapkan fasilitas internet selama BDR.

Persepsi dari pihak penyelenggara mengenai keterbatasan siswa/ orang tua dalam menggunakan media online tidak sejalan dengan pernyataan orang tua, padahal menurut Watie menyatakan saat ini penggunaan media online seperti medsos, WA, facebook, IG bukan lagi hal yang baru, hampir semua orang memiliki dan mengetahui cara penggunaannya [12]. Diperlukan penggalian data yang mendalam untuk memastikan persepsi pihak penyelenggara BDR dalam mengimplementasikan kebijakan BDR di wilayahnya.

\section{KESIMPULAN}

Berdasarkan hasil penelitian dapat disimpulkan bahwa implementasi belajar dari rumah (BDR) di Provinsi Jawa Barat: 1) Persiapan dan perencanaan, dilakukan melalui surat edaran Mendikbud dan Pemda disambut sekolah dan diteruskan dengan melakukan sosialisasi kepada warga sekolah dan orang tua melalui media sosial, guru membuat perencanaan BDR melalui daring dengan aplikasi; 2). Proses, media dan sumber pembelajaran, dilakukan secara daring melalui media sosial, Facebook, WA, IG, Youtube dan video; 3) Kendala, kendala yang dihadapi guru berupa keterbatasan kuota/jaringan, kesulitan mengontrol siswa sedangkan bagi orang tua akses internet dan terbatasnya fasilitas gadget serta kesulitan mengatur waktu dan proses mendampingi anak belajar; dan 4). Dampak BDR, target kurikulum tidak secara optimal tercapai, penilaian akhlaq sulit dilakukan.

Bagi orang tua dampak BDR yakni: 1) kesempatan dekat dengan anak; 2) dapat mendampingi anak belajar dan memahami kesulitan anak dan guru di sekolah; 3) anak menjadi keranjingan menggunakan gadget dan bermain 'games'; 4) kebutuhan gadget, pulsa dan listrik jadi meningkat.

Saran bagi pemerintah khususnya Pemerintah Daerah Kab./ Kota dan Provinsi Jawa Barat antara lain: 1). Menyiapkan infrastruktur berupa jaringan internet yang meluas ke semua daerah yang disubsidi oleh pemerintah khusus bagi keperluan BDR; 2). Melatih semua guru agar memiliki keterampilan digital teknologi dan keterampilan mengelola pembelajaran daring. Bagi Sekolah, harus menyiapkan perangkat dalam penilaian diluar pengetahuan (afektif siswa) bekerja sama dengan orang tua; 3) Membuat komunitas pembelajaran digital yang memungkinkan bagi semua guru untuk berkomunikasi, bekerja sama dan berbagi pengetahuan dan keterampilan berbagai indormasi dan keterampilan digital.

\section{UCAPAN TERIMA KASIH}

Terimakasih kepada semua pimpinan, petugas LPMP Jawa Barat, Pimpinan Fisip, Jurusan Komunikasi Universitas Pasundan dan responden Disdik Kab./ Kota di Jawa Barat, Disdik Provinsi Jawa Barat serta seluruh orang tua siswa semua jenjang yang telah memberikan data/ informasi serta memberi dukungan terhadap survey impelementasi BDR

\section{DAFTAR PUSTAKA}

[1] Pusdatin Kemdikbud, "Pusdatin Kemdikbud," Kemdikbud, 11 April $2020 . \quad$ [Online]. Available: https://pusdatin.kemdikbud.go.id/pembelajaran-online-di-tengahpandemi-covid-19-tantangan-yang-mendewasakan/. [Accessed 15 April 2020].

[2] P. Jehamun, "Dilema Pembelajaran Dalam Jaringan (Daring) Pada Masa Pandemi Covid-19," Bernas News, 26 April 2020. [Online]. Available: https://bernasnews.com/dilema-pembelajaran-dalamjaringan-daring-pada-masa-pandemi-covid-19/.[Accessed 04 September 2020].

[3] A. P. Kasih, "Orangtua "Menyerah" Mengajar Anak di Rumah? Lakukan 5 Tips Ini," Kompas.com, 31 Maret 2020. [Online]. Available:https://edukasi.kompas.com/read/2020/03/31/151646971/o rangtua-menyerah-mengajar-anak-di-rumah-lakukan-5-tips ini?page $=$ all. [Accessed 22 September 2020].

[4] Kemdikbud, Surat Edaran Nomor 2 Tahun 2020 tentang Pencegahan dan Penanganan Covid-19, Jakarta: Kemdikbud, 2020

[5] C. A. Wedemeyer and R. Nejam, AIM: From concept to reality: The Articulated Instructional Media Program at Wisconsin, Syracuse, NY: Syracuse University Press, 1969.

[6] A. Zuhairi and E. Wahyono, "Universitas Terbuka," 30 Juni 2017 [Online]. Available: http://repository.ut.ac.id/6345/.

[7] Munir, "Direktori File UPI," 30 Oktober 2015. [Online]. Available: http://file.upi.edu/Direktori/FPMIPA/PRODI._ILMU_KOMPUTER/ 196603252001121

MUNIR/BUKU/PEMBELAJARAN\%20JARAK\%20JAUH\%20BE RBASIS\%20TEKNOLOGI\%20INFORMASI\%20DAN\%20KOMU NIKASI\%20\%28TIK\%29.pdf.

[8] D. Keegan, Distance Learning, London: Routledge, 1990.

[9] W. I. Shramm, The Process Effects of Mass Communication, Urbana: University of Illinois Press, 1954.

[10] Z. Finali and C. Zahroul Fitriyah, "Refresentasi Komunikasi dalam Interaksi Sosial," Widyagogik Universitas Trunojoyo, vol. 4, no. 2 , pp. 119-125, 2017.

[11] F. Scheuren, "What is a survey?," 01 Juni 2004. [Online]. Available: https://www.unh.edu/institutionalresearch/sites/default/files/pamphlet.pdf.

[12] E. D. S. Watie, "Komunikasi dan Media Sosial (Communications and Social Media)," Jurnal The Messenger, pp. Vol 3, No 2 (2011), 2011

[13] S. Sofiana, "Kendala Belajar di Rumah, Orang Tua Mengaku Kewalahan karena Minimnya Penjelasan Materi," Surabaya, 2020.

[14] R. J. Stiggins, Student Centered Classroom Assessment, New York: Macmillan College Publishing Company, 1994.

[15] Kementerian Pendidikan dan kebudayaan, "JDIH Kementerian Pendidikan dan Kebudayaan," Kementerian dan Kebudayaan, $04 \mathrm{Me}$ 2007.[Online].Available:https://jdih.kemdikbud.go.id/?service $=$ srv:0 5.14jdih\&ref $=$ yd10cg9c8f11a4a2bbqn4183264t361 cf5f7ab69b21xbr 4a09c5552f6c87f033z82e3v4peas8fe0477cj333b\#106fu0a87b335b8 4406weoe88230fcab80b9h91e0ikc. [Accessed 22 September 2020]. 
[16] Kementerian Pendidikan dan Kebudayaan, Materi Pendukung Gerakan Literasi Nasional: Literasi Digital, Jakarta: Kementerian Pendidikan dan Kebudayaan, 2017.

[17] L. Stafford, Maintaining Long-distance and Cross-residential Relationships, LEA's communication series, Ohio: Lawrence Erlbaum Associates Publishers, 2005.

[18] M. E. Rogers and D. L. Kincaid, Communication Networks: Toward a New Paradigm for Research, California: Free Press, 1981.

[19] W. Ascher and B. Hirschfelder-Ascher, Revitalizing political psychology: the legacy of Harold D. Lasswell, Ney Jersey: Lawrence Erlbau Associates Publisher, 2005. 